УДК 159.964.21

DOI 10.11603/2411-1597.2021.1.12067

\title{
ПРОБЛЕМА КОНФЛІКТІВ У СЕСТРИНСЬКИХ КОЛЕКТИВАХ
}

\author{
А. С. Ширяєва \\ Тернопільський національний медичний університет \\ імені І. Я. Горбачевського МОЗ України
}

\begin{abstract}
Одним 3 найголовніших завдань реформування сестринської справи є зміна ставлення медичних сестер до професії, свого місця в лікувальному закладі. Успіх діяльності організації значною мірою залежить від відносин, що складаються між колегами, керівництвом і підлеглими. Тому керівники середнього медичного персоналу повинні значну увагу приділяти своєчасному виявленню та вирішенню конфліктних ситуацій, сприяти розвитку неформальних відносин у колективі.
\end{abstract}

\section{THE PROBLEM OF CONFLICTS IN NURSING TEAMS}

\section{A. S. Shyriaieva}

\section{Horbachevsky Ternopil National Medical University}

One of the most important tasks of nursing reform is to change the attitude of nurses to their profession, and their place in the hospital. The success of the organization largely depends on the relationship between colleagues, management and subordinates. Therefore, the leaders of nursing teams should pay considerable attention to timely detection and resolution of conflict situations, to promote the development of informal relations inside the teams.

Вступ. Особливістю професійного середовища медичних працівників $\epsilon$ те, що практично кожна сфера їх діяльності передбачає роботу в команді, наприклад в операційній бригаді, або постійну взаємодію з колегами (із суміжними, допоміжними підрозділами, іншими фахівцями свого відділення), а також спілкування $з$ пацієнтами та їхніми родичами. Незважаючи на те, що кожен учасник процесу надання медичної допомоги виконує власні безпосередні професійні обов'язки, так чи інакше всі співробітники медичної організації пов'язані один з одним. Напруженість праці медичних працівників (висока відповідальність, фізичні та емоційні навантаження, відсутність чіткого розмежування обов'язків, стандартів сестринської діяльності тощо) призводить до виникнення суперечок, суперництва, непорозуміння між співробітниками спричиняє різного роду конфлікти.

Основна частина. 3 позиції психології та управління персоналом конфлікти в трудовому колективі [3, 5], зокрема медсестринському, можуть виникати:

- на соціально-побутовому ґрунті (наприклад, хтось регулярно не миє за собою чашку, не витирає ноги перед входом до відділення тощо);

(с) А. С. Ширяєва, 2021
- на політичному ґрунті (розбіжності в політичних поглядах)

- на релігійному ґрунті (різне ставлення до віросповідання, народження, життя, смерті та, відповідно, до абортів, евтаназії тощо);

- на фінансовому ґрунті (різний рівень заробітної плати співробітників, необґрунтоване, на думку ініціатора конфлікту, зниження/підвищення заробітної плати, позбавлення премії, дискримінація в отриманні додаткового заробітку тощо);

- на професійному ґрунті (розбіжності в застосуванні методик надання допомоги, недопрацювання, помилки в роботі тощо);

- змішані конфлікти, що виникають відразу з кількох причин.

Конфліктні ситуації в професійному середовищі $\epsilon$ великою неприємністю для адміністративно-управлінської ланки та самих співробітників (за винятком спеціально спровокованих), оскільки знижують якість праці та продуктивність, погіршують психоемоційний клімат у колективі аж до повної зупинки (блокування) робочого процесу; в конфлікти можуть бути «втягнуті» треті особи (С. Калаур) [1]. Іноді буває складно передбачити, хто вийде переможцем у конфліктній ситуації, 
який буде результат і ціна перемоги, які будуть втрати (економічні, кадрові тощо), тому конфліктів краще уникати.

Професійні конфлікти можуть виникати на різних рівнях. Горизонтальні конфлікти виникають між співробітниками, які не перебувають у підпорядкуванні один до одного (між медичними сестрами, санітарками, змінами, між співробітниками одного рівня різних підрозділів) [2]. Вертикальні конфлікти виникають між співробітниками, які перебувають в підпорядкуванні один до одного, і залежно від ініціатора можуть бути висхідними або нисхідними. Трудові конфлікти також залежно від ініціаторів та активності сторін можуть бути зустрічними, односторонніми, багатосторонніми, дворівневими, багаторівневими, змішаними тощо. За результатами конфлікти можуть бути повністю або частково вирішені, удавано вирішені [3].

Наведемо приклад багаторівневого змішаного конфлікту. У міську клінічну лікарню прийняли нову завідуючу відділенням, яка відразу захотіла поміняти старшу медсестру, незважаючи на те, що співробітники відділення були проти кадрових перестановок. Усі співробітники позитивно відгукувалися про діючу старшу медсестру. Однак, буквально через півтора місяці, нова завідуюча «переманила» на свою сторону сестру-господиню, збільшивши їй преміальні виплати і пообіцявши за «дружбу» додаткові преференції, і ще кількох медсестер, за якими тягнувся шлейф серйозних помилок у роботі, а в деяких були і дисциплінарні стягнення. Також нова завідуюча розповсюдила у відділенні неправдиву інформацію про те, що старша медсестра погано відгукувалася про колег. 3 цього моменту в колективі стали відбуватися постійні конфлікти між співробітниками різних сторін і рівнів. Більшість середнього і молодшого медперсоналу, не погодившись з діями нової завідуючої і її нових «друзів», неодноразово просили головну медсестру прийти у відділення і залагодити конфлікт, письмово зверталися до головного лікаря лікарні, неодноразово записувалися до нього на прийом, щоб висловити свою думку стосовно ситуації у відділенні, однак ні головна медсестра лікарні, ні головний лікар не знайшли часу на вирішення цього конфлікту. У результаті співробітники, не витримавши такого ставлення, написали листи «у всі інстанції» - у профспілки, комісії з питань праці, прокуратуру, до депутатів Верховної Ради України, в департамент охорони здоров'я міста щодо порушення етико-моральних, трудових прав працівників з боку адміністрації лікарні, включаючи головну медсестру і головного лікаря. Необхідно сказати, що в цьому випадку активну позицію з від- стоювання прав діючої старшої медсестри займав саме персонал відділення, а не вона сама (вона неодноразово писала заяви на звільнення за власним бажанням, але на вимогу колективу вимушена була відкликати їх). Конфлікт мав деструктивно-негативний характер.

Причинами конфліктів між головною медсестрою і старшими медсестрами можуть бути: проблеми із забезпеченням витратними матеріалами (їх кількість, якість, розподіл); обтяження співробітників матеріальною відповідальністю, передача, облік, зберігання матеріальних цінностей; документообіг (розробка документів, ведення обліково-звітної документації, нечіткість наказів тощо); контроль діяльності підлеглих (методи контролю); порушення комунікацій (нечітке, несвоєчасне, вибіркове доведення відомостей, наказів та іншої інформації до підлеглих); порушення етичних норм професійного і міжособистісного спілкування [6].

Основою причинно-наслідкових зв'язків виникнення конфліктів у професійному середовищі можуть бути розбіжності, перешкоди в досягненні цілей (первинних, вторинних, особистих), відторгнення норм сформованих відносин у колективі (спотворення понять «субординація», «професіоналізм», «повага до старших»). Однією з причин конфліктів можуть бути характерні, індивідуальні особливості індивіда (індивідів), наприклад конфліктність особистості, упертість, неуважність, висока вимогливість до себе і до оточуючих, прагнення влади/лідерства, амбітність, дефекти виховання.

Приклад конфліктів через індивідуальні особливості індивіда. Одна медична сестра, закінчивши факультет вищої медсестринської освіти, за період з 2010 до 2020 р. встигла поміняти 5 робочих місць. Треба відзначити, що скрізь вона працювала на посаді головної медсестри або заступника головного лікаря з середнього медичного персоналу, дуже успішно проходила співбесіду, етапи відбору, добре проявляла себе під час випробувального терміну. Однак звільнялася, посварившись з усім керівництвом і колективом. Постійно її не влаштовували головні лікарі та їх заступники, старші медсестри відділень. Спілкування з середнім і молодшим медперсоналом вона вважала нижче своєї гідності. У всіх місцях їі трудова діяльність починалася з критики існуючого в медичній організації порядку і бажання все поміняти згідно зі своїми уявленнями і без урахування думки підлеглих.

Першопричиною конфліктів $\in$ конфліктогени (від лат. - спричиняє конфлікт) - слова, будь-які дії або бездіяльність. Однак не завжди конфліктогени спри- 
чиняють відкритий конфлікт. Серед конфліктогенів виокремлюють: прагнення до лідерства, навіть з боку будь-якого співробітника, рядового («хоч ти і головна/старша медсестра, а я все одно досвідченіша»), до агресії (природна, ситуативна агресія), егоїзм [4].

Окреслимо причини виникнення конфліктів. Так, в основі виникнення конфлікту в професійному середовищі можуть лежати:

1) організаційно-правові, адміністративно-управлінські, соціально-психологічні причини/чинники: невизначений правовий і низький (незаслужено занижений і недооцінений) соціальний статус працівників; нерозмежованість зони відповідальності; нерівномірне навантаження на персонал; відсутність норм навантаження і чітких критеріїв/показників діяльності; низькі можливості або повна відсутність можливостей зростання (зокрема особистісного, кар'єрного); особливості взаємин з адміністративно-управлінським персоналом (керівники і підлеглі, керівники різного рівня); відсутність або неприйняття співробітниками системи цінностей організації (місії, мети тощо); недостатньо добре організована система оцінки персоналу, праці, якості, заохочень; невідповідність трудової діяльності функціональним обов'язкам (рівню підготовки); несприятливі умови праці; відсутність лідерських якостей у керівника; наявність неформальних лідерів тощо;

2) порушення в інформаційній логістиці медичної організації, комунікативних зв'язків: нечітке, спотворене доведення інформації (наказів, методичних рекомендацій вищих інстанцій, внутрішніх розпоряджень, локальних документів), блокування інформації, надмірні потоки інформації;

\section{СПИСОК ЛІТЕРАТУРИ}

1. Калаур С. М. Методологія розробки тренінгів для формування готовності у майбутніх фахівців соціальної сфери до розв'язання професійних конфліктів / С. М. Калаур // Соціальна робота і соціальна педагогіка: виклики сьогодення : зб. наук. праць за матеріалами VI всеукр. наук.-практ. конф. (Тернопіль, 17-18 трав. 2017 р.). - Тернопіль : ФОП Осадца Ю. В., 2017. - С. 44-48.

2. Тихомирова $Є$. Б. Конфліктологія та теорія переговорів : підручник / Є. Б. Тихомирова, С. Р. Постоловський. Суми : ВТД «Університетська книга», 2008. - 240 с.

3. Балабанова Л. В. Конфліктологія : навч. посіб. / Л. В. Балабанова, К. В. Савельєва. - К. : Видавничий дім «Професіонал», 2009. - 280 с.

4. Корнещук В. В. Конфлікт як соціально-педагогічна проблема / В. В. Корнещук // Науковий вісник Миколаїв-
3) недостатній рівень знань: низький рівень базової підготовки фахівців, вузький світогляд і відсутність прагнення до його розширення, пізнання, підвищення компетентності;

4) поведінкові причини: низький рівень культури співробітників і/або керівництва, відсутність чітких норм організаційної поведінки, негативне ставлення до колег, деструктивна поведінка (нахабство, грубість, ненависть, нетерпимість, порушення правил), девіантна поведінка окремих співробітників.

За часовими межами, інтенсивністю, фазами перебігу конфлікти можуть бути тривалі, уповільнені, короткочасні, швидкоплинні, затяжні, активні, пасивні, вибухові, одноразові. Конфлікти також поділяють на спонтанні, прогнозовані, спровоковані, з передвісниками, локальні, розлиті (широкомасштабні). Залежно від цього у керівника (у особи, зацікавленої у вирішенні конфлікту) $є$ можливість прогнозувати, керувати конфліктною ситуацією [7].

Висновки. Ми коротко розглянули причини виникнення, врегулювання та вирішення конфліктів з організаційної та адміністративно-управлінської позиції. Важливо пам'ятати, що більшість конфліктів, особливо спонтанних, «незапланованих», «пущених на самоплив», має деструктивний характер. Неадекватне реагування з позиції керівництва спричиняє негативні наслідки і проявляється в стійкому зниженні якості виконуваної роботи (особистості, групи й організації загалом), послаблення лідерських позицій адміністрації організації та самого керівника, порушення морально-психологічного клімату в колективі, зміни організаційної поведінки, переосмислення цінностей. А це, водночас, $є$ пусковим чинником виникнення нових конфліктів.

ського національного університету імені В. О. Сухомлинського. - 2015. - № 3. - С. 115-118.

5. Психологія : підручник / за ред. Ю. Л. Трофімова. - К. : Либідь, 2001. - 558 с.

6. Тихомирова Є. Б. Конфліктологія та теорія переговорів : підручник / Є. Б. Тихомирова, С. Р. Постоловський. Рівне : Перспектива, 2007. - 389 с.

7. Трухан М. А. Практичні підходи до організації соціально-психолого-педагогічного тренінгу як форми конфліктологічної підготовки майбутніх соціальних педагогів / М. А. Трухан // Наукові записки [Ніжинського державного університету ім. Миколи Гоголя]. Психолого-педагогічні науки. - 2014. - № 4. - С. 183-187. 